\title{
What is Published in Human Morphology? Types of Designs and Levels of Evidence
}

\author{
¿Qué se Publica en Morfología Humana? Tipos de Diseños y Niveles de Evidencia
}

"Iván Suazo Galdames \& **,***Carlos Manterola D.

SUAZO, G. I. \& MANTEROLA, D. C. What is published in human Morphology? Types of designs and levels of evidence. Int. J. Morphol., 28(2):461-470, 2010.

SUMMARY: Evidence-based medicine (EBM) employs the best available evidence in a particular time and context to solve specific clinical problems. This method of practicing medicine has been adopted by most of the disciplines involved in medical training; however, morphology appears to remain beyond this paradigm. The first step in evidence-based practice based on morphology is to recognize the types of studies being conducted with regard to morphology, followed by the assessment of the level of evidence that they provide, which is the purpose of this study. We designed a bibliometric study, in which journals in the Master Journal List of Thomson Reuters, selected using the keywords "Morphology" or "Anatomy," available between 2007 and 2008, with access to full text in electronic version, whose languages were English and Spanish, and which only considered studies on human morphology, were included. We analyzed a total of 790 articles, of which $93.1 \%$ were descriptive, $6.5 \%$ were analytical, and $0.4 \%$ were experimental design types. According to the stage of the study, most of the articles (94.8\%) accounted for prevalence and differential diagnosis studies, concentrating on numerous designs such cross-section, which gave complex evidence (1c). The use of these methodologies for the systematic morphological knowledge allowed us to widen our research to generate clinically useful recommendations or merely a teaching approach based on the systematic morphological knowledge available.

KEY WORDS: Evidence-based morphology; Evidence-based medicine; Research design; Bibliometrics; Level of evidence.

\section{INTRODUCTION}

Evidence-based medicine (EBM) employs the best available evidence in a particular time and context to solve specific clinical problems (Sackett et al., 2000). This new paradigm was developed by a group of physicians and epidemiologists at McMaster University, who discussed, consolidated, and systematized the concept of EBM. Currently, EBM is an integral part in the training of health professional undergraduate and postgraduate degree, as well as in everyday clinical practice. In this context, the concepts of the levels of evidence and grades of recommendation generated from them should be understood for the modern practice of medicine (Upshur, 2003; Atkins et al., 2004). The purpose of this form of medical practice is to try to achieve more valid and truthful knowledge from scientific research, which is more valid and reliable for decisionmaking.
At present, the assessment of the scientific community based on this form of medical practice has been extended to almost all areas of teaching involved; however, morphology, which plays a fundamental role in medical training, seems to remain out of this paradigm.

What are the sources of morphological knowledge? There are three basic sources that serve the students to develop a cognitive level and understanding of the organization of the normal human body structures and processes involved in its development. Classical literature in gross anatomy was mainly derived from French, German, and later, the American schools, while microscopic anatomy demonstrated a strong German and Spanish influence; furthermore, development anatomy centered on the German, English, and American influence. The opinion of educational

\footnotetext{
* Universidad de Talca, Chile.

** Department of Surgery, Faculty of Medicine, Universidad de La Frontera, Temuco, Chile.

*** CIGES (Training, Research and Management for health based on evidence) Faculty of Medicine, Universidad de La Frontera, Temuco, Chile.
} 
experts in the course of training and academic background to build valuable acquis shapes and to contextualize the classical knowledge was usually based on this knowledge (the source most used by students to consolidate their knowledge). The scientific literature is represented by indexed journals accessed through search engines, electronic databases, and ad hoc strategies (these have had an explosive growth in all the areas of knowledge, consequently resulting in the development of EBM). Nevertheless, the importance of providing these updated knowledge databases, using the latter source of knowledge on morphology, has not been properly developed and applied in morphological teaching in clinical areas, slowing the progress of this paradigm in this area of basic science.

A student needs to acquire cross-morphological knowledge that will be helpful in numerous clinical situations. A first step in evidence-based practice with respect to morphology is to recognize the types of studies being conducted in morphology, followed by the assessment of the level of evidence that they provide.

Accordingly, the objective of this study is to observe and describe the different types of designs that are published on human morphology and the levels of evidence that they provide.

\section{MATERIAL AND METHOD}

Design: Bibliometric study.

Population: The journals included in this study were selected as follows: journals in the Master Journal List of Thomson Reuters selected using the keywords "Morphology" or "Anatomy," published in 2007 and 2008, with access to full text in electronic publishing, and whose languages were English and Spanish were included. The journals that met these selection criteria were analyzed for their mission, aims, scope, and thematic content, excluding those that did not consider human morphology at one of its levels (macroscopic, microscopic, and developmental), or if its main emphasis was on the description of animal or insect species and their evolutionary relationships, with little connection with human morphology or the applicability of these studies in clinical medicine.

Sampling: A non-probability sampling of the aforementioned morphology journals was performed (Fig. 1).

1. Analysis of the Articles: From the selected journals, only articles from human morphology were selected, which were classified and analyzed by principal investigation operators, using the classification of evidence levels and recommendation grades of Evidence-Based Medicine Center from the University of Oxford, which was updated on March 2009 (CEBM, 2009).

Definitions: The studies were classified according to their design in accordance with the following description:

1. Descriptive Studies: These studies aim to "watch" and "describe" the characteristics of the variable under study in a group of individuals or segments of them acting as units of study.

1.1 Review and case series: The more common designs found in scientific journals do not have a comparison group. They consist of careful and detailed description of clinical cases, cadaver dissection, biopsy material, macerated skulls, etc., and the only difference between them is the number of subjects studied (Manterola, 2001; Manterola, 2009). Thus, when the number of cases under consideration is less than or equal to 10 , the report is indicated as cases (e.g., Ossification of the sella turcica and clinoid ligaments, a case report, morphological study, and literature review (Suazo et al., 2008b)), and when the number of cases under consideration is greater than 10 , it is considered as a case series. In turn, the series of cases may be retrospective and prospective, with the only difference being the fact that the data are generated as the object of study in the longitudinal axis of time, so that in one case, the data generated in the past and present are shown (e.g., Anatomical study of the pterygospinous and pterygoalar bony bridges and foramens in dried crania and its clinical relevance (Suazo et al., 2009a)), and in the other, the data are generated and collected from the present and future (e.g., Inferior alveolar nerve block anesthesia via retromolar triangle, an alternative for patients with blood discrasias (Galdames et al., 2008)). In both the cases, the results can be presented as descriptive statistics, with calculation of averages, measures of central tendency, and dispersion (mean, median, mode, standard deviation, etc.).

1.2 Cross-section studies: These studies show the distribution of a condition or characteristic under study in a population of individuals or segments of them at one point in time. Its key feature is that all measurements are made at one time, and hence, no follow-up periods are needed (Manterola, 2001; Manterola, 2009; e.g., Is the conduct of Serres an anatomical variation in adults? (Suazo et al., 2009b)).

1.3 Correlational studies: These studies seek to establish correlation between different variables (two or more), 


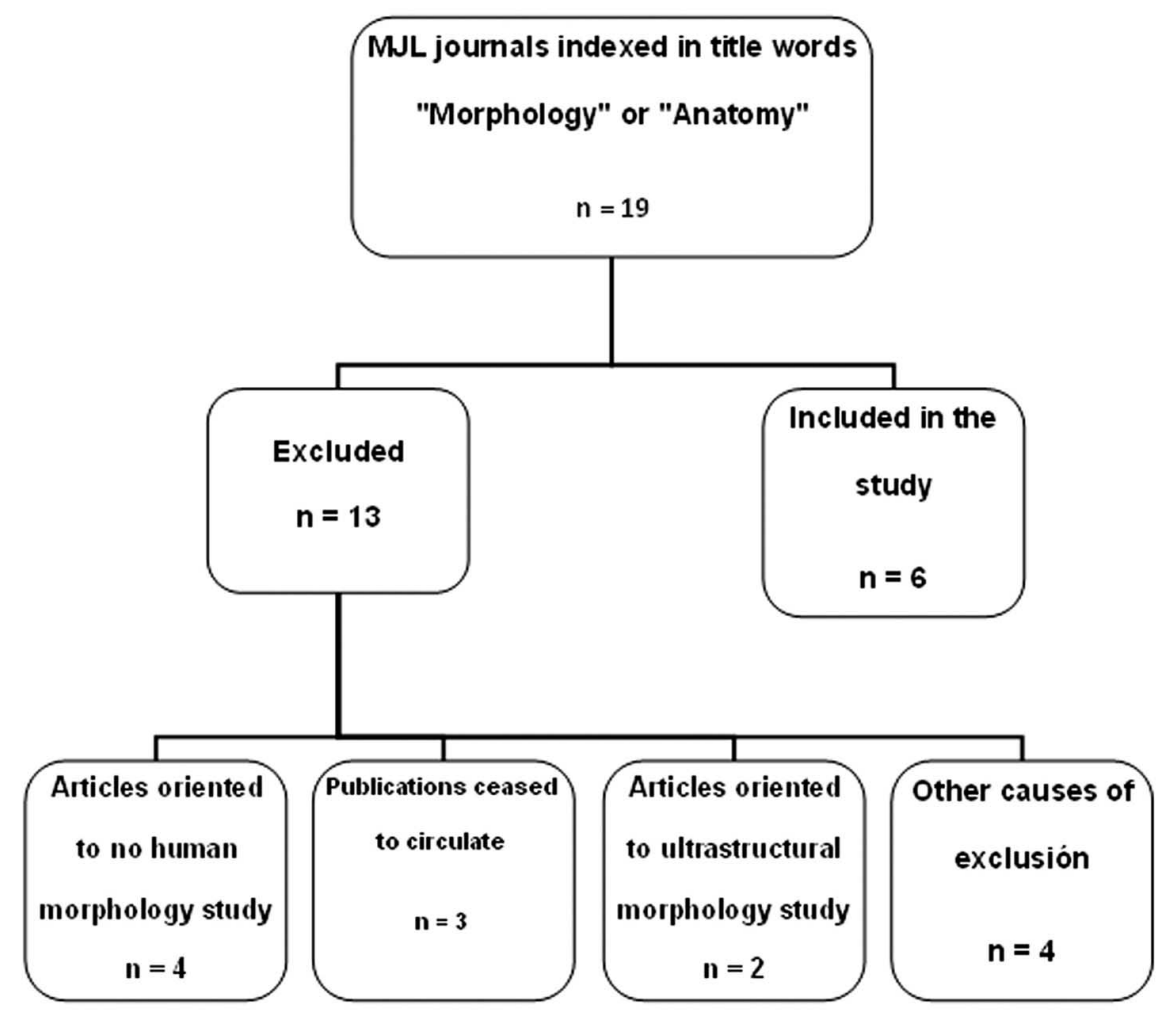

Fig. 1. Flowchart of the selection of journals studied. MJL: Master Journal List. Other parameters for exclusion: Short-book-type publication, publication of abstracts only with articles aimed at the consequences of genetic alterations and architecture journals, one of each.

determining the degree and direction of the relationship between them, from individuals or segments of them (e.g., Relationship between volume and cephalic Pterygopalatine fossa and upper facial indexes (Coronado et al., 2008)).

1.4 Population studies: These studies are conducted on large populations. They are used to provide data on efficacy and safety of interventions or community interest, to know the behavior of a variable in the same population at different periods of time (e.g., Results of a study on populational colorectal cancer screening (Courtier et al., 2009)).

2. Analytical studies: They aim to "watch" and "analyze" two or more groups of individuals or segments of them, under different variables analyzed, thus allowing to compare and generate statistical inference, i.e., applied descriptive statistics, bivariate analysis, and multivariate analysis.

2.1 Case and control studies: These studies are based on the generated data collection, and are therefore retrospective. They allow comparative analysis of a group of subjects who had developed a condition or event of interest, such as an anatomical variation, dysmorphosis, or illness (called "cases"), with a group of individuals who are normal (called "controls"). Therefore, the objective is to determine whether the frequency of occurrence of a variable under study is different in the "cases" and "controls" (e.g., Comparisons in soft-tissue thickness on the human face in fresh and embalmed corpses using needle puncture method (Suazo et al., 2008a)).

2.2 Cohort studies: A cohort is a group of subjects followedup to observe the appearance of an "event of interest," such as a disease, dysmorphosis, abnormal development, etc. (e.g., lack of fusion of the maxillary palatine processes), known as the outcome or dependent variable, and on the other hand, the existence of an "exposure factor," that can predict the outcome variable (predictor or independent). A comparison is made between the groups of subjects, with respect to the risk factors that are believed to be associated with the development of the condition or event of interest. Cohort studies can be retrospective, prospective, or concurrent historical, among which only the time in which they are generated and when the data are collected, varies (e.g., from the present to the past in historical cohorts-Treatment of condylar fractures: A retrospective cohort study (Carneiro et al., 2008); and from the present into the future in the concurrent cohort: Twenty-year cohort study of health gain 
from orthodontic treatment: Temporomandibular disorders (Macfarlane et al., 2009)).

2.3 Studies of diagnostic tests: These studies evaluate the performance of a diagnostic test in terms of, at least, accuracy and sensitivity. Therefore, they require a comparison of two groups of subjects: one with and one without the condition of interest in the study (e.g., Performance evaluation as a diagnostic test for traditional methods for forensic identification of sex (Suazo et al., 2009c)).

\section{Experimental.}

3.1 Clinical trials: These studies evaluate the effect of an intervention, such as drug treatments, surgical procedures, experimental lesion, etc., on a group of subjects against another group that did not receive it (e.g., Morphologic changes in the pineal gland of rat after elimination of retinal photic stimulation (Roa et al., 2008)).

3.2 Field test: These are studies in which treated individuals who have the condition tested are at risk of developing it.

3.3. Community essay: These studies are used to test a hypothesis and are designed considering an experimental group and a control. The main feature is that the intervention and control groups do not consist of individuals chosen unintentionally, but comprise the entire communities. In these designs, intervention and randomization exist (e.g., Energy-dense diets are associated with lower diet costs: a community study of French adults (Darmon et al., 2004)).

4. Reviews: There are articles that discuss about a particular topic or research problem based on the available literature.

4.1 Narrative: A type of review in which the search is not systematic, and in which the author develops the theme based on experience, specific knowledge, and accessed literature (e.g., Toxicity of Sucralose in Humans: A Review (Rodero et al., 2009)).

4.2 Systematic: This type of study provides a summary of the existing research on a specific question, using explicit and systematic methods of identification, critical appraisal, and synthesis of scientific literature (Sacket et al.; e.g., Gross Morphology of the Vastus lateralis Muscle: An Anatomical Review (Becker et al., 2009)). These studies may or may not comprise meta-analysis (statistical tool for combining the results of these studies by obtaining aggregates; e.g., Single site meta-analysis of $6 \%$ hydrogen peroxide whitening strip effectiveness and safety over 2 weeks (Gerlach et al., 2009)).
5. Historical: This group of articles includes those related to medical history, morphology, etc. Furthermore, it also includes recollections and references to key figures in memoriam (e.g., Erasistratus of Ceos (310-250 AC). Pioneer of the Anatomical Studies (Romero, 2008)).

6. Editorial: These are opinion pieces written by the editor of the journal or members of its editorial board (e.g., Scientific Plagiarism, is Also Present in the Morphologic Sciences (del Sol, 2007)).

7. Letters: They are short communications addressed to the editor of the journal, which include discussions, criticisms, compliments, or response to criticisms about the articles published earlier or relevant facts relating to the subject area of the magazine (e.g., Critics on "Demonstration of an anomalous connection between the left coronary artery and the pulmonary artery using a multislice CT 64 " by Castorina et al. (Muresian, 2008)).

8. Others: They include articles that do not fit into any of the categories of this classification, such as book reviews, conference abstracts, opinion articles, erratum, methods, etc.

2. Analysis plan: The data were recorded on a table, and after an exploratory data analysis, descriptive statistics were applied to calculate the percentages. The different studies evaluated were classified according to the level of evidence and grade of recommendation that they provide, according to the classification of CEBM.

\section{RESULTS}

There were 19 journals within the search strategy. We included journals such as Annals of anatomyAnatomischer anzeiger, Clinical Anatomy, Journal of Anatomy, Surgical and Radiologic Anatomy, International Journal of Morphology, and Romanian Journal of Morphology and Embryology. The following journals were excluded: Advances in Anatomy Embryology and Cell Biology; American Journal of Anatomy; Anatomical Record-Advances in Integrative Anatomy and Evolutionary Biology; Italian Journal of Anatomy and Embryology; Anatomy and Physiology Journal of Applied Immunohistochemistry and Molecular Morphology; European Journal of Morphology; Journal of Animal Morphology and Physiology; Journal of Morphology; Journal of Morphology and Physiology; Journal of Nematode Morphology and Systematics; and Medical Molecular Morphology and Urban Morphology (see Fig. 1). 
We reviewed all the articles published in the six journals $(\mathrm{n}=1482)$ selected, and among those that satisfied the eligibility criteria in the study period, 360 articles were not related to human morphology. Furthermore, from the total of 1112 articles analyzed, 322 articles $(28.95 \%)$ were excluded because they corresponded to communications of various kinds, such as literature reviews, presentation of methods or techniques, or those that were not research papers, namely, editorials, letters to the editor, book reviews, etc. (Fig. 2). Thus, the number of items studied was 790 . The breakdown of the number of issues and articles with respect to the year of publication is summarized in Table I.

The remaining $71.04 \%(\mathrm{n}=790)$ consisted of studies on human morphology, most of them corresponding to descriptive studies (93.1\%), with the most common design

Table I. Summary of items considered with respect to journal and year of publication. 1Excluding studies of human morphology. 2The year 2007 there were 17 articles in German, of which 11 corresponded to books review, 4 in memoriam, 1 article of education and 1 of opinion. 3In 2008 there were 41 articles in German, of which 40 corresponded to books review and 1 In memoriam.

\begin{tabular}{|c|c|c|c|c|c|}
\hline & $\begin{array}{l}\text { Issues per } \\
\text { year }\end{array}$ & $\begin{array}{l}\text { n Articles } \\
2007\end{array}$ & $\begin{array}{l}\text { n Articles } \\
2008\end{array}$ & $\begin{array}{l}\text { n Total } \\
\text { Articles }\end{array}$ & $\begin{array}{l}\text { Total analyzed } \\
\text { Articles }\end{array}$ \\
\hline Journal of Anatomy & 12 & 149 & 150 & 299 & 139 \\
\hline Annals of Anatomy & 6 & $94^{2}$ & $96^{3}$ & 190 & 93 \\
\hline Clinical Anatomy & 8 & 200 & 158 & 358 & 354 \\
\hline $\begin{array}{l}\text { Romanian Journal of } \mathrm{M} \text { orphology and } \\
\text { Embriology }\end{array}$ & 4 & 52 & 89 & 141 & 137 \\
\hline Surgical \& Radiology Anatomy & 8 & 111 & 114 & 225 & 224 \\
\hline International Journal of Morphology & 4 & 126 & 143 & 269 & 165 \\
\hline Total & 42 & 732 & 750 & 1482 & 1112 \\
\hline
\end{tabular}

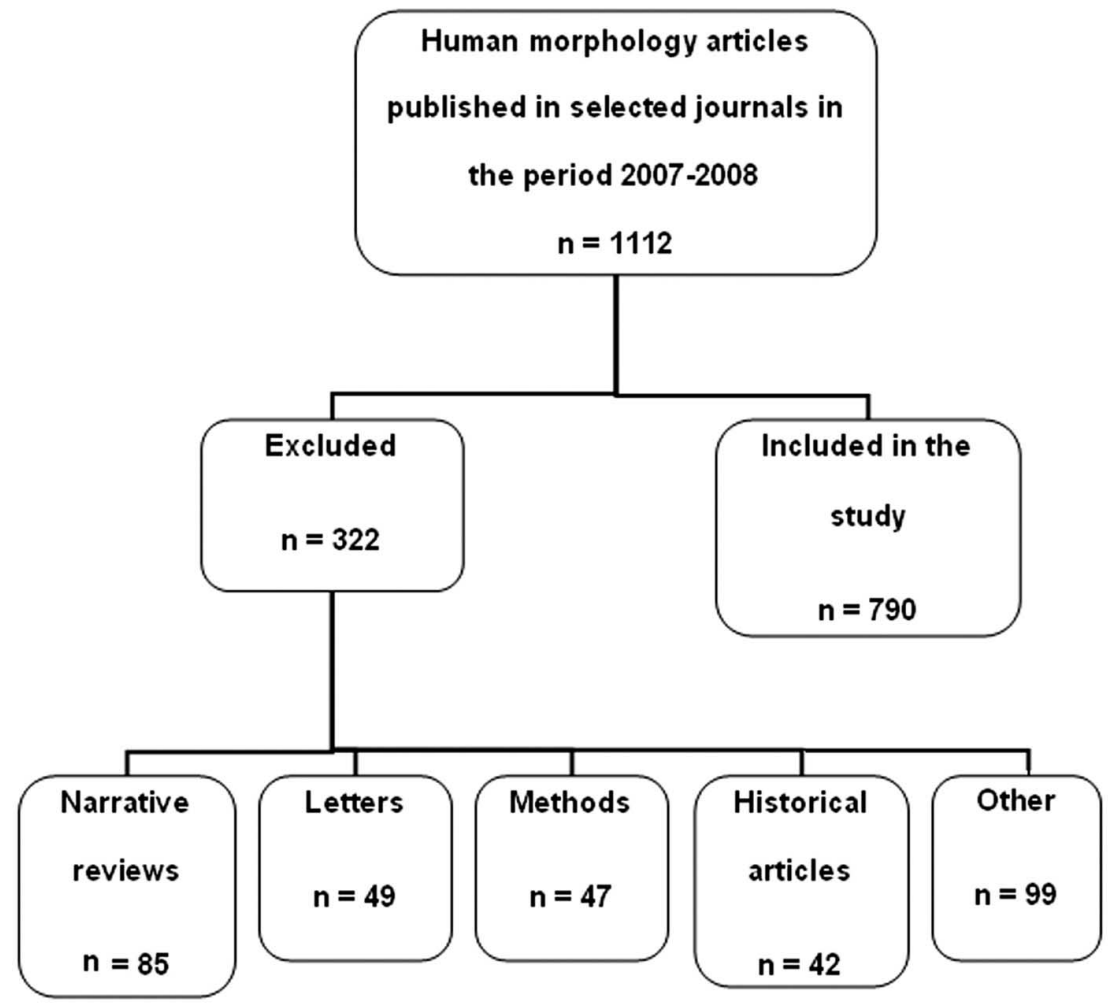

Fig. 2. Flowchart of the selection of articles studied. Other: Systematic review (1 item), Publishing (7), Miscellaneous (91). 
Table II. Distribution of the designs during 2007-2008 in the journals studied.

\begin{tabular}{llrr}
\hline \multirow{2}{*}{ Descriptive (93.1\%) } & Desing type & Frequency & $\%$ \\
\cline { 2 - 4 } & Case report & 223 & 28.2 \\
& Retrospective Case Series & 84 & 10.6 \\
& Prospective Case Series & 4 & 0.5 \\
& Cross section & 402 & 50.9 \\
& Correlational & 23 & 2.9 \\
& Case-control & 28 & 3.5 \\
& Retrospective cohort & 2 & 0.3 \\
& Prospective cohort & 5 & 0.6 \\
& Diagnostic tests & 16 & 2.0 \\
& Clinical trials & 3 & 0.4 \\
& Total & 790 & 100.0
\end{tabular}

being cross-section (50.9\%). The details of these results are presented in Table II.

In general, the higher prevalence of descriptive studies to examine the journals repeated independently. The distribution of the types of design magazines is analyzed in Table III.

According to the stage of study, most of the articles (94.8\%) corresponding to prevalence studies and differential diagnosis concentrated on numerous designs, such crosssection, which demonstrated a high level of evidence (1c), according to CEBM (Table IV).

\section{DISCUSSION}

The ever-increasing number of articles posted each day on various bibliographic databases, makes it increasingly difficult to maintain an updated knowledge on any subject area, including the field of morphology. However, it is believed that everything has already been described, and it has been determined that the scientific literature on problems of human morphology is maintained within the possible limits to address a fact, which allows the development of studies like our study. Furthermore, the space occupied by the publications on human morphology is clear.

The analytical and experimental designs, according to the classification of all forms of evidence levels and grades of recommendation, provide better quality data, which, in our study were very much negligible (less than $7 \%$ ).

Most of the studies analyzed were of descriptive designs, such report and case series, a situation which is strange, because anatomical variations occur with great frequency, and that any morphologist may observe that their finding coincides with DiDio (1970), who observed that anatomical variation is the most common finding. According to Inzunza (2008), these studies are of great importance in medical training and in preparing the learner with the certainty of unpredictable anatomical variations. Despite the obvious importance of this knowledge, clinical decisions are made based on the perspective of the level of evidence that provide nothing more than stories of experts and opinions of the author, which is not applicable to a particular patient.

Owing to numerous articles based on series of cases developed in the area of morphology, in many subjects, these studies are the best-available evidence. Such designs give us better quality information based on the number of samples analyzed, the data available in the sample (age, gender, weight, size, biotype, etc.), the proper description of the procedures performed (dissection, cutting, processing histological staining techniques and/or marking, etc.), and their reproducibility.

A special type of scenario where a case series can provide a better level of evidence is the quantitative morphometry using unbiased stereology, in which only a few specimens (4 or 5) are used for estimating size, number, and volume. These methods are widely used in microscopic anatomy and development (Furrianca et al., 2008; Valenca et al., 2008; Vásquez \& del Sol, 2009). Though the value of the delivered data is not reflected in the level of evidence that they provide, it cannot be concluded that studies that use stereology provide poor information. This contradiction clearly demonstrates the need for classification systems and 
SUAZO, G. I. \& MANTEROLA, D. C. What is published in human Morphology? Types of designs and levels of evidence. Int. J. Morphol., 28(2):461-470, 2010.

Table III. Distribution of the designs during 2007-2008 in the journals.

\begin{tabular}{|c|c|c|c|}
\hline \multicolumn{2}{|l|}{ Journal } & \multirow{2}{*}{$\begin{array}{r}\text { Frecuency } \\
8\end{array}$} & \multirow{2}{*}{$\begin{array}{r}\boldsymbol{\%} \\
5.8\end{array}$} \\
\hline Journal of & Case report & & \\
\hline \multirow[t]{13}{*}{ Anatomy } & Retrospective Case & 13 & 9.4 \\
\hline & Cross section & 25 & 18.0 \\
\hline & Correlational & 2 & 1.4 \\
\hline & Case-control & 5 & 3.6 \\
\hline & Prospective cohort & 1 & .7 \\
\hline & Diagnostic tests & 2 & 1.4 \\
\hline & Narrative review & 35 & 25.2 \\
\hline & Historical & 5 & 3.6 \\
\hline & Editorial & 2 & 1.4 \\
\hline & Letters & 1 & .7 \\
\hline & Other & 21 & 15.1 \\
\hline & Methods & 19 & 13.7 \\
\hline & Total & 139 & 100.0 \\
\hline Annals of & Case report & 23 & 24.7 \\
\hline \multirow[t]{14}{*}{ Anatomy } & Retrospective Case & 6 & 6.5 \\
\hline & Prospective Case & 2 & 2.2 \\
\hline & Cross section & 25 & 26.9 \\
\hline & Correlational & 1 & 1.1 \\
\hline & Case-control & 5 & 5.4 \\
\hline & Prospective cohort & 1 & 1.1 \\
\hline & Diagnostic tests & 2 & 2.2 \\
\hline & Narrative review & 1 & 1.1 \\
\hline & Historical & 14 & 15.1 \\
\hline & Editorial & 6 & 6.5 \\
\hline & Letters & 1 & 1.1 \\
\hline & Other & 4 & 4.3 \\
\hline & Methods & 2 & 2.2 \\
\hline & Total & 93 & 100.0 \\
\hline Clinical & Case report & 63 & 17.8 \\
\hline \multirow[t]{15}{*}{ Anatomy } & Retrospective Case & 24 & 6.8 \\
\hline & Cross section & 134 & 37.9 \\
\hline & Correlational & 5 & 1.4 \\
\hline & Case-control & 2 & .6 \\
\hline & Retrospective cohort & 1 & .3 \\
\hline & Diagnostic tests & 6 & 1.7 \\
\hline & Clinical trials & 1 & .3 \\
\hline & Narrative review & 14 & 4.0 \\
\hline & Systematic review & 1 & .3 \\
\hline & Historical & 24 & 6.8 \\
\hline & Editorial & 2 & .6 \\
\hline & Letters & 36 & 10.2 \\
\hline & Other & 35 & 9.9 \\
\hline & Methods & 6 & 1.7 \\
\hline & Total & 354 & 100.0 \\
\hline
\end{tabular}

increased levels of evidence to consider a particular context in this type of morphological studies.

The prospective case series used in the study of embryonic development allowed us to observe changes at different stages of development. Such designs also allowed

\begin{tabular}{|c|c|c|c|}
\hline Romanian & Case report & 54 & 39.4 \\
\hline \multirow{10}{*}{$\begin{array}{l}\text { Journal of } \\
\text { Morphology and } \\
\text { Embriology }\end{array}$} & Retrospective Case & 23 & 16.8 \\
\hline & Prospective Case & 1 & .7 \\
\hline & Cross section & 35 & 25.5 \\
\hline & Correlational & 3 & 2.2 \\
\hline & Case-control & 4 & 2.9 \\
\hline & Prospective cohort & 2 & 1.5 \\
\hline & Narrative review & 8 & 5.8 \\
\hline & Historical & 4 & 2.9 \\
\hline & Methods & 3 & 2.2 \\
\hline & Total & 137 & 100.0 \\
\hline \multirow{13}{*}{$\begin{array}{l}\text { Surgical \& } \\
\text { Radiology } \\
\text { Anatomy }\end{array}$} & Case report & 38 & 17.0 \\
\hline & Retrospective Case & 15 & 6.7 \\
\hline & Prospective Case & 1 & .4 \\
\hline & Cross section & 114 & 50.9 \\
\hline & Correlational & 6 & 2.7 \\
\hline & Case-control & 3 & 1.3 \\
\hline & Diagnostic tests & 2 & .9 \\
\hline & Narrative review & 2 & .9 \\
\hline & Editorial & 1 & .4 \\
\hline & Letters & 11 & 4.9 \\
\hline & Other & 26 & 11.6 \\
\hline & Methods & 5 & 2.2 \\
\hline & Total & 224 & 100.0 \\
\hline \multirow{14}{*}{$\begin{array}{l}\text { International } \\
\text { Journal of } \\
\text { Morphology }\end{array}$} & Case report & 37 & 22.4 \\
\hline & Retrospective Case & 3 & 1.8 \\
\hline & Cross section & 69 & 41.8 \\
\hline & Correlational & 6 & 3.6 \\
\hline & Case-control & 9 & 5.5 \\
\hline & Diagnostic tests & 6 & 3.6 \\
\hline & Clinical trials & 1 & .6 \\
\hline & Narrative review & 12 & 7.3 \\
\hline & Historical & 3 & 1.8 \\
\hline & Editorial & 1 & .6 \\
\hline & Letters & 1 & .6 \\
\hline & Other & 5 & 3.0 \\
\hline & Methods & 12 & 7.3 \\
\hline & Total & 165 & 100.0 \\
\hline
\end{tabular}

us to assess the morphological characteristics of the present groups of subjects who were subjected to special conditions, such as training or a special diet; however, they were only considered to be representative of the population analyzed in the absence of allocation procedures for random or control groups.

The way the study assessed the evidence provided by morphological studies needs to be analyzed and discussed on many occasions, as there were cross-sectional studies with a very low number of specimens, in contrast to studies conducted on a sample, obtained by random assignment, using a sampling method, or which were simply more numerous. Though these studies responded to the same 
SUAZO, G. I. \& MANTEROLA, D. C. What is published in human Morphology? Types of designs and levels of evidence. Int. J. Morphol., 28(2):461-470, 2010.

Table IV. Scenarios, designs, and levels of evidence according CEBM classification.

\begin{tabular}{|c|c|c|c|}
\hline Scene & Design & Level of evidence & Frecuency \\
\hline \multicolumn{4}{|c|}{ Treatment } \\
\hline & Retrospective cohort & 4 & 1 \\
\hline & Prospective cohort & $2 b$ & 2 \\
\hline & Total & & 3 \\
\hline \multicolumn{4}{|c|}{ Prognosis } \\
\hline & Retrospective Case Series & 4 & 1 \\
\hline & cross-section & 4 & 2 \\
\hline & Correlational & & 1 \\
\hline & Case-control & $2 b$ & 6 \\
\hline & Prospective cohort & $1 b$ & 2 \\
\hline & Clinical trials & $1 b$ & 2 \\
\hline & Total & & 14 \\
\hline \multicolumn{4}{|c|}{ Diagnosis } \\
\hline & Case report & 4 & 2 \\
\hline & Prospective Case Series & 4 & 1 \\
\hline & Correlational & & 1 \\
\hline & Case-control & 4 & 6 \\
\hline & Prospective cohort & $3 b$ & 1 \\
\hline & Diagnostic tests & $1 \mathrm{c}$ & 13 \\
\hline & Total & & 24 \\
\hline \multicolumn{4}{|c|}{ Prevalence and diferencial diagnosis } \\
\hline & Case report & 4 & 221 \\
\hline & Retrospective Case Series & 4 & 83 \\
\hline & Prospective Case Series & 4 & 3 \\
\hline & cross-section & $1 \mathrm{c}$ & 400 \\
\hline & Correlational & & 21 \\
\hline & Case-control & $2 b$ & 16 \\
\hline & Retrospective cohort & $2 b$ & 1 \\
\hline & Diagnostic tests & & 3 \\
\hline & Clinical trials & & 1 \\
\hline & Total & & 749 \\
\hline
\end{tabular}

design, the relevance of the data was different. Therefore, it may be important to generate scales that incorporate variable sample size to estimate the best available evidence or at least provide the "quality of reporting" or even "methodological quality," on multidimensional construct in the field of clinical medicine (Manterola et al., 2006a; Manterola et al., 2006b), which will cause a line of research in the field of human morphology, which was the aim of this study.

This is also important with respect to the meta- analysis of the information that these studies provide. When we analyzed a set of studies concerning a topic of interest based on morphology, such as different aspects of gross anatomy of the vastus lateralis (Becker et al.), namely, the number of fascicules, motor points, and provision of microvasculature, the articles determined were crosssectional studies on good design, especially with a good description of the sample and methodology used, which provided the best available evidence and allowed us to observe, in the best group, cases considered in different metaanalysis studies, as well as to generate additional value to 
these designs. It is possible that the implementation of a formal meta-analysis in this area is unlikely; however, we have developed alternative methodologies that have allowed us to meta-analyze the data from different types of items with designs by calculating the weighted mean and further comparison between the groups (Manterola et al., 2005a; Manterola et al., 2005b).
The use of these methodologies for the systematic morphological knowledge has allowed us to widen our research to generate clinically useful recommendations or simply a teaching approach based on the systematic morphological knowledge available. We have termed this proposal as "The beginning of the evidence-based morphology" (Galdames \& Delgado, 2009).

SUAZO, G. I. \& MANTEROLA, D. C. ¿Qué se publica en morfología humana? Tipos de diseños y niveles de evidencia. Int. J. Morphol., 28(2):461-470, 2010.

RESUMEN: La medicina basada en evidencia (MBE), es la utilización de la mejor evidencia disponible en un momento y contexto determinado para la solución de problemas clínicos específicos, esta forma de practicar la medicina ha sido adoptada por la mayor parte de las disciplinas que participan en la formación médica, sin embargo, la morfología pareciera ser que se ha mantenido al margen de este paradigma. Un primer paso para el acercamiento de la morfología a la práctica basada en la evidencia, es reconocer los tipos de estudios que se realizan en morfología, el siguiente será la valoración del nivel de evidencia que ellos aportan, ese es el propósito de este estudio. Se diseñó un estudio bibliométrico, se incluyeron revistas que en el buscador de la Master Journal List de Thomson Reuters respondieron a las palabras de título "Morphology" or "Anatomy", que se encontraban vigentes, con números disponibles los años 2007 y 2008, con acceso a texto completo en versión electrónica y cuyos idiomas de publicación fueran el inglés y español, sólo se consideraron estudios de morfología humana. Se analizó un total de 790 artículos, de los cuales 93,1\% correspondieron a tipos de diseño descriptivo, 6,5\% analíticos y 0,4\% experimentales. De acuerdo al escenario de estudio, la mayor parte de los artículos (94.8\%), correspondió a estudios de prevalencia y diagnóstico diferencial, concentrando una gran cantidad de diseños tipo corte transversal, lo que le otorga un nivel de evidencia elevado (1c). El uso de estas metodologías para sistematizar el conocimiento morfológico nos permitirá mejorar nuestros estudios con el fin de generar recomendaciones de utilidad clínica o simplemente una enseñanza de la morfología basada en el abordaje sistemático del conocimiento disponible.

PALABRAS CLAVE: Morfología basada en evidencia; Medicina basada en evidencia; Diseños de investigación; Bibliometría; Niveles de evidencia.

\section{REFERENCES}

Atkins, D.; Best, D.; Briss, P. A.; Eccles, M.; Falck-Ytter, Y.; Flottorp, S.; Guyatt, G. H.; Harbour, R. T.; Haugh, M. C.; Henry, D.; Hill, S.; Jaeschke, R.; Leng, G.; Liberati, A.; Magrini, N.; Mason, J.; Middleton, P.; Mrukowicz, J.; O'Connell, D.; Oxman, A. D.; Phillips, B.; Schünemann, H. J.; Edejer, T. T.; Varonen, H.; Vist, G. E.; Williams, J. W. Jr.; Zaza, S. \& GRADE Working Group. Grading quality of evidence and strength of recommendations. BMJ, 328:1490-4, 2004.

Becker, I.; Woodley, S. J. \& Baxter, G. D. Gross morphology of the vastus lateralis muscle: An anatomical review. Clin. Anat., 22:436-50, 2009.

Carneiro, S.; Vasconcelos, B.; Caldas, A. Jr.; Leal, J. \& Frazão, M. Treatment of condylar fractures: A retrospective cohort study. Med. Oral Patol. Oral Cir. Bucal, 13:E589-94, 2008.

Centre for Evidence-based Medicine (CEBM). Levels of Evidence. Avalaible in: http://www.cebm.net/ index.aspx?o=1025 (accessed July 2009).

Coronado, G. C. A.; Suazo, G. I. C.; Cantín, L. M. G. \&
Zavando, M. D. A. Relationship between Pterygopalatine fossa volume and cephalic and upper facial indexes. Int. J. Morph., 26:393-6, 2008.

Courtier, R.; Casamitjana, M.; Macia, F.; Panades, A.; Castells, X.; Gil, M. J.; Pares, D.; Sanchez-Ortega, J. M. \& Grande, L. Results of a study on populational colorectal cancer screening. Cir. Esp., 85:152-7, 2009.

Darmon, N.; Briend, A. \& Drewnowski, A. Energy-dense diets are associated with lower diet costs: a community study of French adults. Public Health Nutr., 7:21-7, 2004.

Del Sol, M. Scientific Plagiarism, is Also Present in the Morphological Sciences. Int. J. Morphol., 25:671-6, 2007.

DiDio, L. J. A. Sinopsis of Anatomy. 1st Ed. Saint Louis, Mosby, 1970.

Furrianca, M. C.; Vasquez, B. \& del Sol, M. Comparative Stereology between the Spleen of the Guinea Pig (Cavia porcellus) and the Rat (Rattus novergicus, Sprague Dawley). Int. J. Morphol., 26:529-32, 2008. 
Galdames, I. S. \& Delgado, C. M. The beginning of the evidencebased morphology. Clin. Anat., 22:783, 2009.

Gerlach, R. W.; Barker, M. L.; Karpinia, K. \& Magnusson, I. Single site meta-analysis of $6 \%$ hydrogen peroxide whitening strip effectiveness and safety over 2 weeks. J. Dent., 37:360$5,2009$.

Inzunza, O. General competence in medicine, the role of the anatomy. Int. J. Morphol., 26:243-6, 2008.

Macfarlane, T. V.; Kenealy, P.; Kingdon, H. A.; Mohlin, B. O.; Pilley, J. R.; Richmond, S. \& Shaw, W. C. Twenty-year cohort study of health gain from orthodontic treatment: temporomandibular disorders. Am. J. Orthod. Dentofacial Orthop., 135:692-3, 2009.

Manterola, C. Estrategias de investigación: Diseños observacionales 1a Parte. Estudios descriptivos. Rev. Chil. Cir., 53:229-33, 2001.

Manterola, C. Observational studies: the most frequent designs in clinic investigation. Rev. Med. Clin. Condes, 20:539-48, 2009.

Manterola, C.; Pineda, V.; Vial, M.; Losada, H. \& Muñoz, S. Surgery for morbid obesity: selection of operation based on evidence from literature review. Obes. Surg., 15:106-13, 2005a.

Manterola, C.; Pineda, V. \& Vial, M. Open versus laparoscopic resection in non-complicated colon cancer. A systematic review. Cir. Esp., 78:28-33, 2005b.

Manterola, C.; Pineda, V.; Vial, M.; Losada, H. \& MINCIR Group. What is the methodologic quality of human therapy studies in ISI surgical publications? Ann. Surg., 244:82732, 2006a

Manterola, C.; Busquets, J.; Pascual, M. \& Grande, L. What is the methodological quality of articles on therapeutic procedures published in Cirugía Española? Cir. Esp., 79:95100, $2006 b$.

Muresian, H. Critics on "Demonstration of an anomalous connection between the left coronary artery and the pulmonary artery using a multislice CT 64" by Castorina et al. Clin. Anat., 21:606-7, 2008.

Roa, H. I.; Suazo, G. I.; Cantín, L. M. \& Zavando, M. D. Morphologic Changes in Rat's Pineal Gland After Eliminating Retinal Photic Stimulation. Int. J. Morphol., 26:665-8, 2008.

Rodero, A. B.; Rodero, L. D. \& Azoubel, R. Toxicity of Sucralose in Humans: A Review. Int. J. Morphol., 27:239-44, 2009.
Romero, R. R. Erasistratus of Ceos (310-250 AC). Pioneer of the Anatomical Studies. Int. J. Morphol., 26:823-4, 2008.

Sackett, D. L.; Strauss, S. E.; Richardson, W. S.; Rosenberg, W. \& Haynes, R. B. Evidence-based medicine: how to practice and teach EBM. $2^{\text {nd }}$ Ed. London, Churchill-Livingstone, 2000.

Suazo Galdames, I. C.; Cantín López, M. G. \& Zavando Matamala, D. A. Inferior alveolar nerve block anesthesia via the retromolar triangle, an alternative for patients with blood dyscrasias. Med. Oral Pathol. Oral Cir. Bucal, 13:E437, 2008.

Suazo, G. I. C.; Cantín, L. M.; Zavando, M. D. A.; Perez, R. F. J. \& Torres, M. S. R. Comparisons in Soft-Tissue Thicknesses on the Human Face in Fresh and Embalmed Corpses Using Needle Puncture Method. Int. J. Morphol., 26:165-9, 2008a.

Suazo, G. I. C.; Zavando, M. D. A. \& Smith, R. L. Ossification of the Sella Turcica and Clinoid Ligments, Case Report, Morphological Study and Literature Review. Int. J. Morphol., 26:799-801, 2008b.

Suazo, G. I. C.; Zavando, M. D. A. \& Smith, R. L. Anatomical study of the pterygospinous and pterygoalar bony bridges and foramens in dried crania and its clinical relevance. Int. J. Morphol., 2009a, In press.

Suazo, G. I. C.; Zavando, M. D. A. \& Smith, R. L. Is the Conduct of Serres an Anatomical Variation in Adults? Int. J. Morphol., 27:43-7, 2009b.

Suazo, G. I. C.; Zavando, M. D. A. \& Smith, R. L. Performance Evaluation as a Diagnostic Test for Traditional Methods for Forensic Identification of Sex. Int. J. Morphol., 27:116-23, 2009c.

Upshur, R. E. Are all evidence-based practices alike? Problems in the ranking of evidence. CMAJ, 169:672-3, 2003.

Valenca, S. S.; Gouveia, L.; Pimenta, W. A. \& Porto, L. C. Effects of Oral Nicotine on Rat Liver Stereology. Int. J. Morphol., 26:1013-22, 2008.

Vasquez, B \& del Sol, M. Comparative Stereology between the Glands of the Prostatic Complex in the Rabbit Oryctolagus cunniculus. Int. J. Morphol., 27:205-10, 2009.

\section{Correspondence to:}

Dr. Iván Suazo Galdames

Department of Morphology

Universidad de Talca, Avenida Lircay s/n

Talca, CHILE

E-mail: isuazo@utalca.cl

Received: 03-11-2009

Accepted: 22-03-2010 